\title{
Tip 2 Diabetes Mellitus Hastalarında Serum Endokan ve ADMA Düzeylerinin Saptanması ve Diyabetin Komplikasyonları ile İlişkisinin Belirlenmesi
}

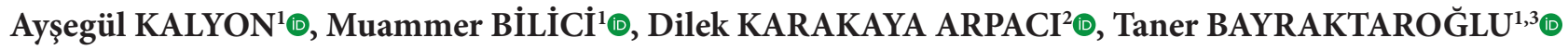 \\ ${ }^{1}$ Bülent Ecevit Üniversitesi, Tip Fakültesi, İç Hastalıkları Anabilim Dalı, Zonguldak \\ ${ }^{2}$ Medikal Park Hastanesi, İç Hastalıkları Bölümü, Gebze, Kocaeli \\ ${ }^{3}$ Bülent Ecevit Üniversitesi, Tıp Fakültesi, İç Hastalıkları Anabilim Dalı, Endokrinoloji ve Metabolizma Hastalıkları Bilim Dalı, Zonguldak \\ Bu makaleye yapılacak atıf: Kalyon A, Bilici M, Karakaya Arpacı D, Bayraktaroğlu T. Tip 2 diabetes mellitus hastalarında serum endokan ve adma düzeylerinin saptanması ve \\ diyabetin komplikasyonları ile ilişkisinin belirlenmesi. Türk Diyab Obez 2018;2: 49-58.
}

\begin{abstract}
ÖZET
Amaç: Endotel disfonksiyonun göstergesi olarak ADMA(Asimetrik Dimetilarginin) ve endokan ölçümünün kullanılabileceğine dair çalışmalar mevcuttur. Bu çalışmada, diyabetik hastalarda serum endokan ile ADMA seviyeleri ölçülmüştür. Serum endokan ve ADMA düzeyleri ile hiperglisemi bağlantılı mikrovasküler komplikasyonlar arasındaki ilişkinin değerlendirmesi amaçlanmıştır.

Gereç ve Yöntemler: Çalışmaya DM (Diabetes Mellitus) tanısı ile takipli ve rutin kontrole gelen 85 diyabetli ve bilinen sistemik hastalığı olmayan 85 gönüllü (kontrol grubu) dahil edildi. Çalışmaya; akut enfeksiyon, malignite tanısı, diyaliz alma ve herhangi bir kronik inflamatuvar hastalık öyküsü olanlar alınmadı. Diyabetiklerde diyabetik nefropati, nöropati ve retinopati ile serum ADMA ve endokan düzeyi arasındaki ilişki incelendi. Hesaplanan $\mathrm{p}<0.05$ düzeyleri istatistiksel olarak anlamlı kabul edildi.

Bulgular: Serum ADMA düzeyleri diyabetik olgu grubunda $[9,42(0,84-52,0) \mathrm{ng} / \mathrm{ml}] \mathrm{kontrol}$ gruba $[5,95(1,68-48,3) \mathrm{ng} / \mathrm{ml}]$ göre anlamlı olarak daha yüksek saptanırken $(\mathrm{p}<0,001)$; diyabetiklerle $[0,42(0,25-1,99 \mathrm{ng} / \mathrm{ml})]$ ve kontrol grubu $[0,45(0,23-1,25) \mathrm{ng} / \mathrm{ml}]$ arasında endokan düzeyleri arasında anlamlı fark saptanmadı $(\mathrm{p}=0,730)$. Mikrovasküler komplikasyonlu diyabetiklerle mikrovasküler komplikasyonu olmayanlar arasında serum ADMA [sırasıly 9,3(0,84-52,0)ng/ml; 9,4(3,1-51,3)ng/ml] ve endokan [sirasiyla 0,43(0,27$1,87) \mathrm{ng} / \mathrm{ml} ; 0,41(0,25-1,99) \mathrm{ng} / \mathrm{ml}$ ] düzeyleri açısından anlamlı fark bulunmadı (sırasıyla $\mathrm{p}=0,884 \mathrm{ve} \mathrm{p}=0,355)$. Diyabetik retinopati ve nöropati saptananlar ile saptanmayanlar arasında serum ADMA ve endokan düzeyleri açısından anlamlı fark bulunmazken; proteinüri saptananlarda saptanmayanlara göre serum ADMA ve endokan düzeyleri anlamlı derecede yüksek tespit edildi (sirasıyla $\mathrm{p}=0,04$ ve $\mathrm{p}=0,030$ ).

Sonuç: Çalışmamız kronik düşük düzey inflamasyonun eşlik ettiği Tip 2 DM hastalarında vasküler disfonksiyon belirteci olarak serum ADMA düzeylerinin kullanılabileceği hipotezini desteklemektedir. Ancak hastalık patofizyolojisinde yer alan inflamasyon göstergesi olarak plazma endokan düzeyleri arasında ilişki bulunamakla birlikte serum ADMA ile endokan düzeylerinin birlikte ölçümünün hastalık progresyonu öngörüsünde ek katkısının kısıtlı olduğu şeklindedir.
\end{abstract}

Anahtar Sözcükler: Diabetes Mellitus, Endotel disfonksiyonu, Endokan, ADMA

\section{Determination of Serum Endocan and ADMA Levels in Patients with Type 2 Diabetes Mellitus and Determination of Their Association With Diabetic Complications}

\begin{abstract}
Aim: Diabetes mellitus (DM) is a chronic metabolic disease with a dramatic increase in prevalence. The current inflammatory process in diabetes mellitus leads to differentiation of the vascular endothelium and consequently microvascular and macrovascular complications. There are studies showing that ADMA and endocan measurement can be used as an endothelial dysfunction indicator. In this study, it
\end{abstract}

DOI: $10.25048 /$ tjdo.2018.168 
was aimed to measure serum endocan and ADMA levels in diabetic patients and to evaluate the relationship between serum endocan and ADMA levels and microvascular complications related to hyperglycemia.

Material and Methods: Eighty-five patients who were diagnosed with type 2 DM and 85 volunteers who did not have known systemic disease were admitted to study. Those with acute infection, diagnosis of malignancy, history of dialysis treatment, and any chronic inflammatory disease are not taken into account. Diabetic nephropathy, neuropathy, and retinopathy were screened in the patients. The relationship between diabetic complications and serum ADMA and endocan levels was examined. Calculated p $<0.05$ levels were considered statistically significant.

Results: Serum ADMA levels were significantly higher in the patient group $[9,42(0,84-52,0)$ ng/ml]when compared to the control group $[5,95(1,68-48,3) \mathrm{ng} / \mathrm{ml}](\mathrm{p}<0.001)$; but there was no significant difference between the patient $[0,42(0,25-1,99 \mathrm{ng} / \mathrm{ml})]$ and control group $[0,45(0,23-1,25) \mathrm{ng} / \mathrm{ml}]$ in terms of endocan levels $(\mathrm{p}=0.73)$. Serum ADMA [respectively 9,3(0,84-52,0)ng/ml; 9,4(3,1-51,3)and endocan [respectively $0,43(0,27-1,87) \mathrm{ng} / \mathrm{ml} ; 0,41(0,25-1,99) \mathrm{ng} / \mathrm{ml}$ ] levels were not significantly different in patients with microvascular complications and without microvascular complications $(\mathrm{p}=0.884$ and $\mathrm{p}=0.355$, respectively). Serum ADMA and endocan levels were not significantly different between patients who have diabetic retinopathy and neuropathy and patients who have not diabetic retinopathy or neuropathy. Serum ADMA and endocan levels were found to be significantly higher in patients diagnosed with proteinuria than in patients without proteinuria ( $\mathrm{p}=0.04$ and $\mathrm{p}=0.03$, respectively).

Conclusion: Our study supports the hypothesis that serum ADMA levels may be used as a marker of vascular dysfunction in DM patients with chronic low-level inflammation. However, since plasma endocan levels, which are an indicator of inflammation in the pathophysiology of disease, cannot be correlated with microvascular complications, it can be interpreted that the additional contribution of serum ADMA and endocan levels together is predictive of disease progression, limitedly.

Key Words: Diabetes Mellitus, Endothelial dysfunction, Endocan, ADMA

\section{GİRIS}

Diabetes mellitus (DM) prevalansı dramatik artış gösteren kronik metabolik bir hastalıktır. Türkiye'deTURDEP-2 araştırmasına göre DM prevalansı \% 13,7’ye ulaşmaktadır(1). Tip 2 DM'deartmış insülin yapımı ile etki bozukluklarına bağlı kronik hipergliseminin neden olduğu ileri glukozilasyon son ürünleri (AGEs) dokularda birikerek hücre içi sinyalizasyonu ve gen ekspresyonu değişikliklerine neden olur. Bunlara ek olarak da AGEs, diyabetik mikrovasküler komplikasyonların patolojisine katkıda bulunan pro-inflamatuvar moleküllerin ve serbest radikallerin salınımına yol açar. Diyabette devam eden inflamatuvar süreç ile damar endotelinde farklılaşmaya ve sonuç olarak mikrovasküler (retinopati, nefropati, nöropati) ve makrovasküler (kardiyovasküler hastalık, serebrovasküler hastalık, periferik damar hastalığı) komplikasyonlara yol açmaktadır(2-4).

ADMA(Asimetrik Dimetilarginin), endojen nitrik oksit sentaz (NOS) inhibitörüdür. ADMA'nın, NOS (nitrik oksit sentetaz) enzimini kompetitif olarak inhibe etmesi sonucu NO sentezini azalttı̆̆ı bilinmektedir (5). Artmış ADMA düzeyleri ile ateroskleroz, endotel disfonksiyonu ve diyabetik komplikasyonlar arasında bir ilişki gösterilmiştir. Literatürde mikrovasküler komplikasyonlar ile ilişkisi hakkında çeşitli çalışmalar vardır.

Endokan (endocan), endotelyal aktivasyonu yansittığı düşünülen vasküler endotelden salınan bir proteoglikandır(6). Endokan'ın, anjiogenezis ve inflamatuvar sürecin regülasyonunda önemli bir role sahip olduğu öne sürülmektedir ve vasküler disfonksiyon belirteci olarak kullanılabileceği düşünülmektedir $(6,7)$. Artan endokan seviyeleri kanser, sepsis, obezite, hipertansiyon ve enfeksiyonda saptanmaktadir.

Endotel disfonksiyonu, ateroskleroz, anjiogenezis, inflamasyon ile vasküler disfonksiyon açısından ADMA ve endokan düzeyleri ölçümünün komplikasyonlarla ilişkisini değerlendirmeye yönelik çalışmalar devam etmektedir. Bu çalışmada, diyabetik hastalarda serum endokan ile ADMA seviyelerini ölçmek ilave olarak serum endokan ve ADMA düzeyleri ile hiperglisemi ilişkili mikrovasküler komplikasyonlar arasındaki ilişkiyi değerlendirmek amaçlanmıştır.

\section{GEREÇ ve YÖNTEMLER}

Çalışmamız Temmuz 2015 ve Ağustos 2015 tarihleri arasında Bülent Ecevit Üniversitesi (BEÜ) İç Hastalıkları Anabilim Dalında gerçekleştirilmiştir. Çalışmaya Tip 2 DM tanısı ile BEÜ Tıp Fakültesi Endokrinoloji Polikliniğinde takip edilen 85 hasta (diyabet olgu grubu) ve bilinen sistemik hastalığı olmayan 85 gönüllü (kontrol grubu) alınmıştır. Hasta grubu için akut enfeksiyonu, malignite tanısı olan, diyaliz alma öyküsü olan olgular ve kontrol grubu için herhangi bir kronik hastalık öyküsü ve akut enfeksiyonu olan olgular çalışma dışı bırakıldı. Araştırma için Bülent Ecevit Üniversitesi Tıp Fakültesi Etik Kurulundan onay alınmıştır (Protokol no: 2015-27-26/05). Çalışmaya alınan tüm olgulara çalışma hakkında bilgi verildi ve olguların rızasının alındığını belgeleyen bilgilendirilmiş onam formu imzalatild.

Çalışmaya dahil edilen diyabetik grup ve kontrol grubunda; cinsiyet, yaş, boy, ağırlık, bel-kalça çevresi, vücut kitle 
indeksi (VKİ), sistolik kan basıncı (SKB) ve diastolik kan basıncı (DKB) değerleri kaydedildi. Vücut Kitle İndeksi = A ğırlık(kg) / Boy (m)2 formülü ile hesaplandı. Hastaların albüminüri ve proteinüri düzeyleri 24 saatlik idrar tetkiki ile değerlendirildi. Retinopati için son 1 yıl içinde yapılmış olan göz dibi muayenesi esas alındı. Nöropati değerlendirilmesinde ise klinik bulgulara göre yapıldı.

Diyabetik ve kontrol grubundan venöz kan örnekleri sabah 8:00-10:00 saatleri arasında alındı. Venöz kan örnekleri bekletilmeden 4000/dk devirde $5 \mathrm{dk}$ santrifüj edildi. Yapılan santrifüj işlemi sonrası elde olunan serum örnekleri daha sonra biyokimyasal analizler yapılmak üzere ependorf tüplere aktarılarak $-80^{\circ} \mathrm{C}$ 'de dondurularak saklandı.

\section{Serum ADMA Ölçümï}

Serum ADMA düzeyleri solid faz sandviç ELISA prensibi ile ticari olarak temin edilen Human ADMA ELISA kiti kullanılarak çalışıldı (Bioassay Technology Laboratory, Shangai, Çin). Test sonuçları 2.5, 5, 10, 20 ve $40 \mathrm{ng} / \mathrm{ml}$ konsantrasyonundaki standartlar kullanılarak oluşturulan kalibrasyon eğrisi ile hesaplandı. Çalışmada Bio-Tek markalı (Vermont, ABD) ELx 50 yıkama cihazı ile yapılırken, ELISA plaklarının okuması 450 nm'de ELx800 ELISA plak okuyucu cihazında gerçekleştirilmiştir. Testin ölçüm aralığı 0.2 ile 60 $\mathrm{ng} / \mathrm{ml}$ 'dir. Yöntemin analitik sensitivitesi $0.1 \mathrm{ng} / \mathrm{ml}$ 'dir.

\section{Serum Endokan Ölçümü}

Serum Endokan düzeyleri solid faz sandviç ELISA prensibi ile ticari olarak temin edilen Human Endokan (Endotelyal hücre spesifik molekül, ESM-1) ELISA kiti kullanılarak çalışıldı (Bioassay Technology Laboratory, Shangai, Çin). Test sonuçları $0.075,0.15,0.3,0.6$ ve $1.2 \mathrm{ng} / \mathrm{ml}$ konsantrasyonundaki standartlar kullanılarak oluşturulan kalibrasyon eğrisi ile hesaplandı. Çalışmada Bio-Tek markalı (Vermont, ABD) ELx 50 yıkama cihazı ile yapılırken, ELISA plaklarının okuması 450 nm'de ELx800 ELISA plak okuyucu cihazında gerçekleştirilmiştir. Testin ölçüm aralığı 0.005 ile $2 \mathrm{ng} / \mathrm{ml}$ 'dir. Yöntemin analitik sensitivitesi $0.0025 \mathrm{ng} / \mathrm{ml}$ 'dir.

\section{İstatistiksel Analiz}

Çalışmanın istatistiksel analizleri SPSS 19.0 yapılmıştır. Niteliksel değişkenlere ait tanımlayıcı istatistikler frekans ve yüzde ile sürekli değişkenler ise medyan, minimum ve maksimum değerleriyle verilecektir. Sürekli değişkenlerin normal dağılıma uygunluğu Shapiro Wilk testi ile incelenmiştir. Normal dağılım göstermeyen değişkenlerin 2 grup karşılaştırmalarında Mann Whitney $U$ testi kullanılmıştır. kategorik değişkenlerin gruplar arası karşılaştırmalarında Pearson ki-kare testi kullanılmıştır. Çalışmadaki tüm istatistiksel karşılaştırmalarda $\mathrm{p}$ değeri 0,05 'in altındaki karşılaştırmalar istatistiksel olarak anlamlı kabul edilmiştir.

\section{BULGULAR}

Çalışmamıza 18- 65 yaş arası, DM tanılı 85 diyabetik ile sağlıklı 85 gönüllü kontrol grubu dahil edildi. Toplamda 170 kişinin $84^{\prime}$ ü $(\% 49,4)$ erkek, 86’ sı $(\% 50,6)$ kadınd. Medyan yaş değeri 55 (28-68) yıl idi. DM tanılı olgu grubunun 37'si $(\% 43,5)$ erkek, 48'i $(\% 56,5)$ kadınd. Kontrol grubunun ise $47^{\prime}$ si $(\% 55,3)$ erkek, 38'i $(\% 44,7)$ kadındı. Cinsiyet bakımından gruplar arasındaki fark anlamlı bulunmadı $(\mathrm{p}=0,125)$.

Çalışmaya alınan kişilerin medyan vücut kitle indeksi (VKİ) $30,4(20,3-68,7) \mathrm{kg} / \mathrm{m}^{2}$ olarak saptand. Ayrıca medyan bel çevresi değeri 98,9 (60-146), medyan kalça çevresi değeri 103,5 (73-150) olarak bulundu.

Diyabetik ve kontrol grubuna ait antropometrik ölçümler ve demografik özellikleri Tablo 1'de verilmiştir.

Diyabetik grupta bakılan parametrelerden açlık kan şekeri için medyan değer 174 (39-445) mg/dl; kreatinin değeri için $0,8(0,4-1,4) \mathrm{mg} / \mathrm{dl}$; AST (Aspartat Aminotransferaz) için 22 (8-68)IU/L; ALT (Alanin Aminotransferaz) için 22 (9-106)IU/L; GGT (Gamma glutamyl transferase) için 30 (11-148)IU/L; total kolesterol için 201 (88-461) mg/dl; LDL (low density lipoprotein) kolesterol için 122 (55-223) mg/dl; HDL (High Density Lipoprotein) kolesterol için 43 (19-71)

Tablo 1: Diyabet ve Kontrol Gruplarında Antropometrik Ölçümler ve Demografik Özellikler

\begin{tabular}{|c|c|c|c|}
\hline $\begin{array}{l}\text { Antropometrik Ölçümler ve } \\
\text { Demografik Özellikler }\end{array}$ & $\begin{array}{c}\text { Diyabetik Hastalar } \\
(n=85)\end{array}$ & $\begin{array}{l}\text { Kontrol Grubu } \\
(\mathbf{n}=85)\end{array}$ & $\mathbf{p}$ \\
\hline Yaş $\left[y 1 l\right.$, medyan $\left.(\min -\mathrm{mak})^{\star}\right]$ & $56(28-68)$ & $52(36-67)$ & 0,093 \\
\hline Cinsiyet(E/K) & $37 / 48$ & $47 / 38$ & 0,125 \\
\hline VKİ $\left[\mathrm{kg} / \mathrm{m}^{2}\right.$, medyan $\left.(\min -\mathrm{mak})^{\star}\right]$ & $32,03(20,9-68,7)$ & $25,6(20,3-35,8)$ & $<0,001$ \\
\hline Bel Çevresi $)\left[\mathrm{cm}, \operatorname{medyan}(\text { min-mak })^{\star}\right]$ & $103(72-146)$ & $94(60-114)$ & $<0,001$ \\
\hline Kalça Çevresi $\left[\mathrm{cm}, \operatorname{medyan}(\text { min-mak })^{*}\right]$ & 106(74-150) & 102(73-138) & 0,004 \\
\hline
\end{tabular}

*min-mak: minimum-maksimum. 
$\mathrm{mg} / \mathrm{dl}$; trigliserid için 188 (62-1762) mg/dl, CRP (C- reaktif protein) $4.13 \pm 2.44 \mathrm{mg} / \mathrm{dl}$ olarak saptand 1 (Tablo 2 ).

Kontrol grubunda bakılan parametrelerden açlık kan şekeri için medyan değer 92 (74-125)(mg/dl); kreatinin değeri için $0,8(0,5-1,3)(\mathrm{mg} / \mathrm{dl}) ;$ AST için 21 (12-56) IU/L; ALT için 19 (8-66)IU/L; GGT için 21 (9-127)IU/L; total kolesterol için 186 (107-265) mg/dl; LDL kolesterol için 112 (50-182)mg/ dl; HDL kolesterol için 49 (29-82)mg/dl; trigliserid için 108 (39-394)mg/dl, CRP 2.43 \pm 1.35 olarak saptand (Tablo 2).

Diyabetik ve kontrol gruplarında bakılan biyokimyasal parametrelerden açlık kan şekeri (AKŞ), kreatinin, AST değerleri arasında anlamlı fark saptanmamış iken; ALT, GGT, Total Kolesterol, LDL, HDL, Trigliserid ve CRP düzeyleri arasından anlamlı fark saptandı (Tablo 2).

Kontrol grubunda medyan sistolik kan basıncı değeri 122 (96-130) $\mathrm{mmHg}$ olarak saptanırken; diyabetiklerde ise 132 (100-170) mmHg olarak saptand. Diyabetikler ile kontrol grubu kıyaslandığında sistolik kan basıncı düzeyleri arasında anlamlı fark tespit edildi $(\mathrm{p}<0,001)$.
Kontrol grubunda medyan diastolik kan basıncı değeri 75 (60-100) mmHg olarak saptanırken; diyabetiklerde ise 76 (42-98) $\mathrm{mmHg}$ olarak saptand. Diyabetikler ile kontrol grubu kıyaslandığında diastolik kan basıncı düzeyleri arasında anlamlı fark tespit edilmedi $(\mathrm{p}=0,241)$.

Kontrol grubunda medyan ADMA değeri 5,95 $(1,68-48,3)$ $\mathrm{ng} / \mathrm{ml}$ olarak saptanırken; hasta grubunda ise $9,42(0,84$ $52,0) \mathrm{ng} / \mathrm{ml}$ olarak saptandi. Diyabetikler ile kontrol grubu kıyaslandığında ADMA düzeyleri arasında anlamlı fark tespit edildi $(\mathrm{p}<0,001)$ (Tablo 3$)$.

Kontrol grubunda medyan Endokan değeri 0,45 (0,23-1,25) $\mathrm{ng} / \mathrm{ml}$ olarak saptanırken; diyabetiklerde ise $0,42(0,25-$ $1,99) \mathrm{ng} / \mathrm{ml}$ olarak saptandi. Diyabetikler ile kontrol grubu kıyaslandığında endokan düzeyleri arasında anlamlı fark tespit edilmedi $(\mathrm{p}=0,73)$ (Tablo 3$)$.

Çalışmaya alınan hasta grubundaki DM tanılı hastaların mikrovasküler komplikasyon oranlarına bakıldığında hastaların 23'ünde $(\% 27,1)$ diyabetik retinopati; $18^{\prime}$ inde $(\% 21,2)$ diyabetik nöropati; 33 'ünde $(\% 38,8)$ diyabetik nefropati saptandi.

Tablo 2: Olguların biyokimyasal parametrelerinin karşılaştırılması

\begin{tabular}{cccc}
\hline Biyokimyasal Parametre & $\begin{array}{c}\text { Diyabetik Hastalar } \\
(\mathbf{n = 8 5}) \\
\text { Median }(\mathbf{m i n}-\mathbf{m a k})^{*}\end{array}$ & $\begin{array}{c}\text { Kontrol } \\
(\mathbf{n = 8 5}) \\
\text { Median(min-mak) }\end{array}$ & $\mathbf{p}$ \\
\hline Açlık kan şekeri (mg/dl) & $174,(39-455)$ & $92,(74-125)$ & $<0,001$ \\
\hline Kreatinin (mg/dl) & $0,8(0,4-1,4)$ & $0,8(0,5-1,3)$ & 0,135 \\
\hline AST (IU/L) & $22(8-68)$ & $21(12-56)$ & 0,347 \\
\hline ALT(IU/L) & $22,0(9-106)$ & $19(8-66)$ & 0,049 \\
\hline GGT (IU/L) & $30(11-148)$ & $21(9-127)$ & $<0,001$ \\
\hline Total Kolesterol (mg/dl) & $201(88-461)$ & $186(107-265)$ & 0,006 \\
\hline LDL-K (mg/dl) & $122(55-223)$ & $112(50-82)$ & 0,025 \\
\hline HDL-K (mg/dl) & $43(19-71)$ & $49(29-82)$ & 0,001 \\
\hline Trigliserid (mg/dl) & $188(62-1762)$ & $108(39-394)$ & $<0,001$ \\
\hline CRP $(\mathrm{mg} / \mathrm{dl})$ & $4.13 \pm 2.44$ & $2.43 \pm 1.35$ & $<0,001$ \\
\hline
\end{tabular}

AST: Aspartat Aminotransferaz,ALT: Alanin Aminotransferaz, GGT: Gamma glutamyl transferase), LDL-K: low density lipoprotein, HDL-K: highdensity lipoprotein CRP: C-reaktif protein, ${ }^{*}$ min-mak: minimum-maksimum

Tablo 3: Diyabet ve Kontrol Gruplarının ADMA ve Endokan Düzeyleri

\begin{tabular}{cccc}
\hline Parametre & $\begin{array}{c}\text { Diyabetik Hastalar } \\
(\mathbf{n}=\mathbf{8 5}) \\
\text { Median }(\mathbf{m i n}-\mathbf{m a k})\end{array}$ & $\begin{array}{c}\text { Kontrol } \\
(\mathbf{n = 8 5}) \\
\text { Median(min-mak) }\end{array}$ & $\mathbf{p}$ \\
\hline ADMA (ng/ml) & $9,42(0,84-52,0)$ & $5,95(1,68-48,3)$ & $<0,001$ \\
\hline Endokan $(\mathrm{ng} / \mathrm{ml})$ & $0,42(0,25-1,99)$ & $0,45(0,23-1,25)$ & 0,73 \\
\hline
\end{tabular}

ADMA: Asimetrik Dimetilarginin, min-mak: minimum-maksimum 
Herhangi bir mikrovasküler komplikasyonu olan DM tanılı hastalar ile mikrovasküler komplikasyonu olmayan DM tanılı hastalar kıyaslandığında her iki grup arasında VKİ, açlık kan şekeri, kreatinin, HDL, trigliserid arasında anlamlı fark saptanırken; bel çevresi, kalça çevresi, HbAlc, AST, ALT, GGT, Total Kolesterol, LDL kolesterol, ADMA ve Endokan düzeyleri arasında anlamlı fark saptanmadı. Herhangi bir komplikasyonu olan DM tanılı hastalarda VKİ, açlık kan şekeri, kreatinin, trigliserid düzeyleri komplikasyonu olmayan DM tanılı hastalara göre anlamlı olarak daha yüksek ve HDL değeri anlamlı olarak daha düşüktü (Tablo 4).

A1C düzeyi ve DM süresi ile ADMA ve endokan düzeyleri arasında korelasyon bulunamadi $(\mathrm{p}>0,05)$.
Hastaların \%55,3'ünde (47 hasta) mikrovasküler bir komplikasyon saptanmış iken; \%44,7'sinde (38 hasta) herhangi bir mikrovasküler komplikasyon saptanmadı.

Retinopati saptanan hastaların $(\mathrm{n}=23)$ medyan ADMA değeri 9,02 (0,84-52,04)ng/ml iken, retinopati saptanmayan hastalarda ( $\mathrm{n}=62)$ median ADMA değeri 9,4 (3,12-52,04) $\mathrm{ng} / \mathrm{ml}$ idi. Retinopati saptanan hastalar ile retinopati saptanmayan hastalar arasında ADMA düzeyleri açısından anlamlı fark saptanmadi $(\mathrm{p}=0,34)$ (Tablo 5).

Retinopati saptanan hastaların ( $\mathrm{n}=23)$ medyan Endokan değeri $0,44(0,27-1,87) \mathrm{ng} / \mathrm{ml}$ iken, retinopati saptanmayan hastalarda (n=62) median Endokan değeri 0,41 (0,25$1,99) \mathrm{ng} / \mathrm{ml}$ idi. Retinopati saptanan hastalar ile retinopati saptanmayan hastalar arasında Endokan düzeyleri açısından anlamlı fark saptanmadi $(\mathrm{p}=0,51)$ (Tablo 5).

Tablo 4: Mikrovasküler Komplikasyonu Olan Diyabetik Olgular ile Mikrovasküler Komplikasyonu Olmayanlarda Parametrelerin Karşılaştırılması

\begin{tabular}{lccc}
\hline \multicolumn{1}{c}{ Parametre } & $\begin{array}{c}\text { Mikrovasküler Komplikasyonu } \\
\text { Olan Diyabetikler } \\
(\mathbf{n = 4 7 )} \\
\text { Median(Min-Mak)* }\end{array}$ & $\begin{array}{c}\text { Mikrovasküler Komplikasyonu } \\
\text { Olmayan Diyabetikler } \\
(\mathbf{n}=\mathbf{3 8}) \\
\text { Median(Min-mak)* }\end{array}$ & p \\
\hline Açlık kan şekeri (mg/dl) & $186(39-455)$ & $157(75-362)$ & 0,042 \\
\hline Kreatinin (mg/dl) & $1,0(0,4-2,2)$ & $0,75(0,5-1,4)$ & 0,002 \\
\hline A1C (\%) & $10,1(6,4-14,5)$ & $8,7(6,2-16)$ & 0,197 \\
\hline AST (IU/L) & $22(11-68)$ & $218-67$ & 0,694 \\
\hline ALT (IU/L) & $22(9-77)$ & $20(10-106)$ & 0,388 \\
\hline GGT (IU/L) & $33(11-100)$ & $26(13-148)$ & 0,105 \\
\hline Total Kolesterol (mg/dl) & $200(124-461)$ & $206(88-287)$ & 0,734 \\
\hline LDL kolesterol (mg/dl) & $116(59-223)$ & $125,5(55-186)$ & 0,754 \\
\hline HDL kolesterol (mg/dl) & $41(19-71)$ & $45(32-55)$ & 0,025 \\
\hline Trigliserid $(\mathrm{mg} / \mathrm{dl})$ & $221(75-1762)$ & $152(62-740)$ & 0,004 \\
\hline ADMA (ng/ml) & $9,3(0,84-52,0)$ & $9,4(3,1-51,3)$ & 0,884 \\
\hline Endokan $(\mathrm{ng} / \mathrm{ml})$ & $0,43(0,27-1,87)$ & $0,41(0,25-1,99)$ & 0,355 \\
\hline
\end{tabular}

A1C: Glikozile Hemoglobin, AST: Aspartat Aminotransferaz, ALT: Alanin Aminotransferaz, GGT: Gamma glutamyl transferase), LDL-K: low density lipoprotein, HDL-K: high-density lipoprotein CRP: C-reaktif protein, ADMA: Asimetrik Dimetilarginin, ${ }^{*}$ min-mak: minimum-maksimum

Tablo 5: Retinopati Saptanan ve Saptanmayan Olgularda ADMA ve Endokan Düzeyleri

\begin{tabular}{cccc}
\hline Parametre & $\begin{array}{c}\text { Retinopati Saptanan Diyabetik Olgular } \\
(\mathbf{n = 2 3}) \\
\text { Median (min-mak)* }\end{array}$ & $\begin{array}{c}\text { Retinopati Saptanmayan Olgular } \\
(\mathbf{n = 6 2}) \\
\text { Median(min-mak)* }\end{array}$ & P \\
\hline ADMA $(\mathrm{ng} / \mathrm{ml})$ & $9,02(0,84-52,04)$ & $9,4(3,12-52,04)$ & 0,34 \\
\hline Endokan $(\mathrm{ng} / \mathrm{ml})$ & $0,44(0,27-1,87)$ & $0,41(0,25-1,99)$ & 0,51 \\
\hline
\end{tabular}

ADMA: Asimetrik Dimetilarginin, min-mak*: minimum-maksimum 
Nöropati saptanan hastaların $(\mathrm{n}=18)$ medyan ADMA değeri 8,89 (4,62-52,04)ng/ml iken, nöropati saptanmayan hastalarda ( $\mathrm{n}=67)$ median ADMA değeri 9,44 (0,84$52,04) \mathrm{ng} / \mathrm{ml}$ idi. Nöropati saptanan hastalar ile nöropati saptanmayan hastalar arasında ADMA düzeyleri açısından anlamlı fark saptanmadı $(\mathrm{p}=0,25)$ (Tablo 6).

Nöropati saptanan hastaların $(\mathrm{n}=18)$ medyan Endokan değeri $0,40(0,27-1,70) \mathrm{ng} / \mathrm{ml}$ iken, nöropati saptanmayan hastalarda ( $\mathrm{n}=67)$ median Endokan değeri 0,42 (0,25$1,99) \mathrm{ng} / \mathrm{ml}$ idi. Nöropati saptanan hastalar ile nöropati saptanmayan hastalar arasında Endokan düzeyleri açısından anlamlı fark saptanmadı ( $\mathrm{p}=0,41$ ) (Tablo 6).

Mikroalbüminüri saptanan hastaların $(\mathrm{n}=33)$ medyan ADMA değeri 9,80 (4,62-52,04)ng/ml iken, mikroalbüminüri saptanmayan hastalarda $(\mathrm{n}=52)$ median ADMA değeri 9,26 (0,84-51,39)ng/ml idi. Mikroalbüminüri saptanan hastalar ile mikroalbüminüri saptanmayan hastalar arasında ADMA düzeyleri açısından anlamlı fark saptanmadı $(\mathrm{p}=0,28)($ Tablo 7$)$.

Mikroalbüminüri saptanan hastaların $(\mathrm{n}=33)$ medyan Endokan değeri $0,44(0,27-1,87) \mathrm{ng} / \mathrm{ml}$ iken, mikroalbü- minüri saptanmayan hastalarda $(\mathrm{n}=52)$ median Endokan değeri $0,39(0,25-1,99) \mathrm{ng} / \mathrm{ml}$ idi. Mikroalbüminüri saptanan hastalar ile mikroalbüminüri saptanmayan hastalar arasında Endokan düzeyleri açısından anlamlı fark saptan$\operatorname{mad}_{1}(\mathrm{p}=0,09)$ (Tablo 7).

Proteinüri saptanan hastaların $(n=26)$ medyan ADMA değeri 10,75 (4,85-52,04)ng/ml iken, proteinüri saptanmayan hastalarda $(n=59)$ median ADMA değeri 9,23 (0,84$51,39) \mathrm{ng} / \mathrm{ml}$ idi. Proteinüri saptanan hastalar ile proteinüri saptanmayan hastalar arasında ADMA düzeyleri açısından anlamlı fark saptand $(\mathrm{p}=0,04)$ (Tablo 8).

Proteinüri saptanan hastaların $(\mathrm{n}=26)$ medyan Endokan değeri $0,49(0,27-1,87) \mathrm{ng} / \mathrm{ml}$ iken, proteinüri saptanmayan hastalarda $(n=59)$ median Endokan değeri 0,41 (0,25$1,99) \mathrm{ng} / \mathrm{ml}$ idi. Proteinüri saptanan hastalar ile proteinüri saptanmayan hastalar arasında Endokan düzeyleri açısından anlamlı fark saptand $(\mathrm{p}=0,03)$ (Tablo 8$)$.

Retinopati, nöropati ve proteinüri saptanan hastalar ADMA ve endokan düzeyleri açısından kontrol grubu ile karşılaştırıldığında; ADMA düzeyleri retinopati, nöropati ve proteinüri saptanan hastalarda kontrol grubuna göre

Tablo 6: Nöropati Saptanan ve Saptanmayan Olgularda ADMA ve Endokan Düzeyleri

\begin{tabular}{cccc}
\hline Parametre & $\begin{array}{c}\text { Nöropati Saptanan Hastalar } \\
(\mathbf{n = 1 8}) \\
\text { Median (min-mak)* }\end{array}$ & $\begin{array}{c}\text { Nöropati Saptanmayan Hastalar } \\
(\mathbf{n}=\mathbf{6 7}) \\
\text { Median(min-mak)* }\end{array}$ & $\mathbf{p}$ \\
\hline ADMA (ng/ml) & $8,89(4,62-52,04)$ & $9,44(0,84-52,04)$ & 0,25 \\
\hline Endokan $(\mathrm{ng} / \mathrm{ml})$ & $0,40(0,27-1,70)$ & $0,42(0,25-1,99)$ & 0,41 \\
\hline
\end{tabular}

ADMA: Asimetrik Dimetilarginin, min-mak*: minimum-maksimum

Tablo 7: Mikroalbüminüri Saptanan ve Saptanmayan Olgularda ADMA ve Endokan Düzeyleri

\begin{tabular}{cccc}
\hline Parametre & $\begin{array}{c}\text { Mikroalbüminüri Saptanan Olgular } \\
(\mathbf{n}=\mathbf{3 3}) \\
\text { Median (min-mak)* }\end{array}$ & $\begin{array}{c}\text { Mikroalbüminüri Saptanmayan Olgular } \\
(\mathbf{n}=\mathbf{5 2})\end{array}$ & $\mathbf{p}$ \\
Median(min-mak)* & $9,26(0,84-51,39)$ & 0,28 \\
\hline ADMA $(\mathrm{ng} / \mathrm{ml})$ & $9,80(4,62-52,04)$ & $0,39(0,25-1,99)$ & 0,09 \\
\hline Endokan $(\mathrm{ng} / \mathrm{ml})$ & $0,44(0,27-1,87)$ & & \\
\hline
\end{tabular}

ADMA: Asimetrik Dimetilarginin, min-mak*: minimum-maksimum

Tablo 8: Proteinüri Saptanan ve Saptanmayan Olgularda ADMA ve Endokan Düzeyleri

\begin{tabular}{cccc}
\hline Parametre & $\begin{array}{c}\text { Proteinüri Saptanan Olgular } \\
(\mathbf{n = 2 6 )} \\
\text { Median (min-mak)* }\end{array}$ & $\begin{array}{c}\text { Proteinüri Saptanmayan Olgular } \\
(\mathbf{n = 5 9 )} \\
\text { Median(min-mak) }\end{array}$ & $\boldsymbol{p}$ \\
\hline ADMA $(\mathrm{ng} / \mathrm{ml})$ & $10,75(4,85-52,04)$ & $9,23(0,84-51,39)$ & 0,04 \\
\hline Endokan $(\mathrm{ng} / \mathrm{ml})$ & $0,49(0,27-1,87)$ & $0,41(0,25-1,99)$ & 0,03 \\
\hline
\end{tabular}

ADMA: Asimetrik Dimetilarginin, min-mak ${ }^{\star}$ : minimum-maksimum 
anlamlı olarak yüksek bulunurken, endokan düzeyleri arasında anlamlı fark saptanmadı (Tablo 9).

Mikroalbüminürisi olan hastalarda median ADMA düzeyi $9,80(4,62-52,04) \mathrm{ng} / \mathrm{ml}$ saptanırken, proteinürisi olan hastalarda 10,75 (4,85-52,04)ng/ml olarak saptandı. Mikroalbüminürisi olan hastalarda median endokan düzeyi $0,39(0,25-1,99) \mathrm{ng} / \mathrm{ml}$ saptanırken, proteinürisi olan hastalarda $0,49(0,27-1,87) \mathrm{ng} / \mathrm{ml}$ olarak saptand. ADMA ve endokan düzeyleri proteinüri saptanan hastalarda mikroalbüminüri saptanan hastalara göre anlamlı olarak yüksek saptandı ( $p$ değeri sırası ile 0,04 ve 0,03 ).

Kontrol grubunda serum ADMA ile endokan düzeyleri arasında negatif yönlü anlamlı zayıf ilişki tespit edildi ( $r=-$ $0,352 ; \mathrm{p}<0,001)$

Hasta grubunda serum ADMA ile endokan düzeyleri arasında pozitif yönlü anlamlı kuvvetli ilişki tespit edildi $(\mathrm{r}=0,781 ; \mathrm{p}<0,001)$

\section{TARTISSMA}

Tip 2 DM, tüm dünyada prevalansı sürekli artış gösteren kronik metabolik bir hastalıktır (8). Artmış insülin yapımı ile insülin duyarlılığında bozulmaya bağlı kronik hipergliseminin neden olduğu ileri glukozilasyon son ürünleri (AGEs) dokularda birikerek hücre içi sinyalizasyonu ve gen ekspresyonu değişikliğine neden olur. Bunlara ek olarak da AGEs, diyabetik mikrovasküler komplikasyonların patolojisine katkıda bulunan pro-inflamatuvar moleküllerin ve serbest radikallerin salınımına yol açar (2). DM'de ortaya çıkan bu kronik düşük dereceli inflamasyon DM'nin mikro ve makrovasküler komplikasyonları için bir risk faktörü olarak kabul edilmektedir $(3,4)$. Bir meta-analiz çalışmasında, DM hastalarında ve mikrovasküler komplikasyonların ortaya çıtığı olgularda vasküler endotelyal disfonksiyona neden olan inflamatuvar sürecin bir belir- teci olarak adiponektin düzeylerinin yüksek olduğu bildirilmiştir(9). Diyabetik komplikasyonların patogenezinde kronik düşük dereceli inflamasyon ve vasküler endotelyal disfonksiyon temel rol oynamaktadır $(3,10-12)$. Kan ve damar duvarı arasında yer alan vasküler endotel; hücresel adezyon ve vasküler tonusun düzenlenmesi, düz kas hücre proliferasyonu, trombozis ve inflamasyonun kontrolü için kritik öneme sahiptir (13). Vasküler endotelin rol aldığı bu kompleks etkileşimlerde gözlenen işlevler bazı mediatörler (nitrik oksit, endotelinler, prostaglandinler gibi) aracıllı̆ıyla yapilmaktadır $(10,14)$. Vasküler endotelyal disfonksiyonda başlıca Nitrik Oksit (NO) salınmasında azalma, yıkımında artma veya vazokonstrüktör mediyatörlerin yapımındaki artışa bağlı vasküler dilatasyonda bozulma ile birlikte adezyon moleküllerinin ekspresyonunda artış gözlenmektedir. Gelișen vasküler endotelyal disfonksiyon ateroskleroz, hipertansiyon, hiperkolesterolemi, böbrek yetmezliği, DM gibi birçok hastalık patofizyolojisinde önemli rol oynamaktadır $(12,14,15)$. ADMA ve endokan düzeyleri ölçümünün endotelyal disfonksiyonun patogenezde rol oynadığı diyabetik komplikasyonlarla ilişkisini değerlendirmeye yönelik çalışmalar devam etmektedir. Bu çalışmada DM hastalarında gözlenen kronik düşük dereceli inflamasyonla ilişkili vasküler endotelyal disfonksiyonun patofizyolojisinde nitrik oksit sentetaz (NOS) enzim aktivite bozukluklarının bir göstergesi olarak ADMA ve endokan'nn yeri değerlendirildi. DM hastalarında kontrol grubuna göre serum ADMA düzeyleri yüksek bulunurken, serum endokan düzeyleri arasında anlamlı bir farklılık saptanmadı.

Ateroskleroz, böbrek yetmezliği, hipertansiyon ve hiperkolesterolemi gibi birçok hastalıkta serum ADMA düzeylerinde artış saptanmıştır $(5,16-20)$. Abbasi ve ark.nın yaptıkları bir çalışmada diyabetik komplikasyonların eşlik etmediği tip 2 diyabet hastaları ile sağlıklı bireylerden oluşan kontrol grubu arasında plazma ADMA düzeyleri karşılaş-

Tablo 9: Retinopati, Nöropati ve Proteinüri Saptanan Olgular ile Kontrol Grubunun ADMA ve Endokan Düzeyleri

\begin{tabular}{lcc}
\hline \multirow{2}{*}{ Komplikasyon } & ADMA & Endokan \\
\cline { 2 - 3 } & Median $(\text { min-mak })^{*}$ & Median(min-mak)* \\
\hline Diyabetik Retinopati & $9,02(0,84-52,04)$ & $0,44(0,27-1,87)$ \\
Kontrol & $5,95(1,68-48,32)$ & $0,45(0,23-1,25)$ \\
$p$ değeri & 0,001 & 0,66 \\
\hline Diyabetik Nöropati & $8,89(4,62-52,04)$ & $0,42(0,27-1,70)$ \\
Kontrol & $5,95(1,68-48,32)$ & $0,45(0,23-1,25)$ \\
$p$ değeri & 0,001 & 0,31 \\
\hline Diyabetik Proteinüri & $10,75(4,85-52,04$ & $0,41(0,27-1,87)$ \\
Kontrol & $5,95(1,68-48,32)$ & $0,45(0,23-1,25)$ \\
$p$ değeri & $<0,001$ & 0,93 \\
\hline
\end{tabular}

ADMA: Asimetrik Dimetilarginin, min-mak ${ }^{*}$ : minimum-maksimum 
tırılmış ve diyabetik grupta anlamlı derece yüksek olduğu bildirilmiş(21).

Konya ve ark.nın yaptıkları çalıșmada, diyabetik hastalarda kardiyovasküler risk faktörü olarak plazma ADMA düzeyleri araştırılmış; çalışmaya dahil edilen 87 tip 2 DM hastası 5 yıl süre ile kardiyovasküler komplikasyonlar gelişimi açısından takip edilmiştir. Kardiyovasküler komplikasyon gelişen hastalarda plazma ADMA düzeyleri anlamlı derecede yüksek bulunmuştur (22).

Yapılan çalışmalarda karşı sonuçlar bulunmuş olması ile birlikte, diyabetik hastalarda artmış plazma ADMA düzeylerinin endotel disfonksiyonunun varlığı ile ilişkili olduğu ve ileride gelişebilecek kardiyovasküler komplikasyonların önemli bir belirteci olduğunu bildiren yayınlar literatürde mevcuttur $(19,20,23)$.

ADMA'nın, NOS enzimini kompetitif olarak inhibe etmesi sonucu NO sentezini azalttığı bilinmektedir. Protein arginin metil transferaz (PRMT) enzimleri ile proteinlerdeki arjinin kalıntılarının metillenmesi ve sonra proteolizi sonucu hücre içinde serbest ADMA sentezi gerçekleşir. Sentezlenen ADMA oranda, dimetilarginin dimetil aminohidrolaz (DDAH) 1-2 enzimlerince hücre içerisinde yıkılır. Dolaşıma geçen ADMA'nın yine büyük bir kısmı başta karaciğer ve böbrek olmak üzere birçok dokuda hücre içine alınarak DDAH enzimleri tarafından metabolize edilir. Dolaşımda bulunan ADMA'nın büyük bir oranda böbreklerden atılımı sağlanır(5).

Bizim çalışmamızda diyabetik hastalar non diyabetiklere göre yüksek plazma ADMA düzeylerine sahipti. Bu durum hipergliseminin ADMA metabolizmasını azaltmasıyla açıklanabilir. Lin ve ark. yaptıkları bir çalışmada invitro endotel hücre kültüründe artmış glukoz düzeylerinin $\mathrm{DDAH}$ enzim aktivitesini inhibe ettiğini göstermişlerdir(24). Yap1lan klinik çalışmalarda artmış kan glukoz düzeyleri plazma ADMA konsantrasyonlarıyla direkt ilişkili bulunmuştur $(19,20)$.

Plazma ADMA düzeylerinin uzun dönem diyabetik komplikasyonların ortaya çıkmasında önemli bir role sahip olduğu öngörülmektedir. Assal ve ark.nın yapmış olduğu çalışmada serum ADMA düzeyleri ile diyabetik nefropati progresyonu ve böbrek fonksiyonları arasındaki ilișki değerlendirilmiștir. Çalıșmaya toplamda 75 diyabetik hasta ve 15 sağliklı kontrol dahil edilerek hastalar normoalbuminürik, mikroalbuminürik, makroalbuminürik, böbrek transplantasyonu sonrası 1. ay ve son dönem böbrek yetmezliği nedeni ile hemodiyalize giren hastalar olmak üzere gruplara ayrılmıştır. Tüm gruplardaki hastaların kontrol grubuna göre daha yüksek ADMA düzeylerine sahip olduğu görülmüştür. Ayrıca serum ADMA düzeyleri ile albuminüri progresyonu ve böbrek fonksiyonlarının kötüleşmesi ile anlamlı pozitif bir korelasyon olduğu bildirilmiştir (25). Sonuç olarak bu çalışmada böbrek fonksiyonu ve proteinürinin kötüleşmesi ile ADMA düzeylerinin artı̧ gösterdiği ortaya konmuştur. Malecki ve ark. tarafından yapılan 182 tip 2 DM hastası ve yaş- cinsiyet eșleștirilmiş 52 sağlıklı gönüllünün dahil edildiği çalışmada, hastalar diyabetik nefropati açısından değerlendirilmiştir (26). Diyabet hastalarının \%38,9'unda retinopati tespit edilmiştir. DM hastalarında kontrol grubuna göre ADMA düzeylerinin yüksek olduğu ve retinopatisi olanlar ve olmayanlar karşılaştırıldığında da retinopatisi olanlarda ADMA düzeylerinin daha yüksek bulunduğu saptanmıştır. Bununla birlikte retinopatisi olan ve olmayan gruplar arasında L-arginin düzeyleri benzer olduğu bulunmuştur. Çalışmamızda, literatürle uyumlu olarak diyabetik retinopati, nefropatisi ve nöropatisi olan hastaların serum ADMA düzeyleri ile kontrol grubu karşılaştırıldığında anlamlı fark bulduk. Ayrıca proteinüri miktarı ile serum ADMA düzeyleri arasında anlamlı bir ilişki saptadık. Serum ADMA miktarının vücuttan ıtrahındaki azalmanın böbrek fonksiyonlarındaki kötüleşmeye bağlı olduğu düşündürmektedir (20).

Diyabetik hastalarda subklinik inflamasyonun eşlik ettiği bilinmektedir. Kronik subklinik inflamasyonun diyabet progresyonu ve diyabetik mikro ve makrovasküler komplikasyon gelişmesi açısından risk faktörü olduğu bildirilmektedir $(4,15,27)$. Vasküler endotelden salınan endokan, bir dermatan sülfat proteoglikan olup; anjiogenezis ve inflamatuvar sürecin regülasyonunda önemli bir role sahip olduğu öne sürülen vasküler disfonksiyon belirtecidir $(6,7)$. Endokan ekpresyonunun proinflamatuvar moleküller (TNF-alfa, IL-1) ve büyüme faktörlerinin (VEGF, FGF-2) varlığında arttığ 1 gösterilmiştir (7). Köse ve ark. akut koroner sendromlu hastalarda endokan düzeylerini değerlendirmişlerdir. Hastaların kontrol grubuna göre endokan düzeyleri yüksek bulunmuştur. Ayrıca diyabetik hastaların non diyabetiklere göre daha yüksek endokan düzeylerine sahip olduklarını bildirmişlerdir (28). Buna göre akut koroner sendromlu hastalarda endotelyal patolojinin bir göstergesi olarak endokan'ın kullanılabileceği sonucuna varmışlardır. Asrar ve ark. proliferatif diyabetik retinopatili hastaların vitröz sıvı örneklerinde endokan düzeyi ile hastalık aktivitesi ve anjiogenetik belirteçler arasındaki ilişkiyi araştırmışlardır. Diyabetik hastalarda kontrol grubuna göre endokan düzeylerinin anlamlı yüksek olduğunu saptamış, ayrıca endokan düzeyi ile hastalık aktivitesi ve VEGF düzeyleri ile endokan düzeyleri arasında pozitif bir korelasyon gösterdiğini ortaya koymuşlardır. Endokan'ın diyabetik retinopatili hastalarda anjiogenez ilişkili endotelyal hücre aktivasyonunu yansıtabileceği öngörülmüştür(29). Çalışmamızda diyabetik retinopati saptanan olgular ile saptanmayanlar arasinda serum endokan düzeyleri açısından anlamlı fark saptanmadi. Arman ve ark. kronik böbrek hastalığı ve kronik 
inflamatuvar hastalık öyküsü olmayan 77 diyabetik hastada 3 aylık hayat tarzı değişikliği ve medikal tedavi uygulaması sonrası hastalarda endokan düzeyini değerlendirmişlerdir (30). Hastalarda kontrol grubuna göre endokan düzeyleri yüksek saptanmıştır. Ayrıca tedavi sonrasında idrar albümin/kreatinin oranındaki düşüşle plazma endokan düzeyleri arasında korelasyon olduğu bildirilmiştir. Diyabetik nefropatinin erken safhasında hiperglisemiye bağlı gelişen değişikliklerin, artmış VEGF'nin ilişkili olduğu anormal anjiogenezis ve glomerüler hipertrofi ile birlikte olması ve VEGF'nin endokan artışına aracılık etmiş olabileceği düşünülmüştür. Tedavi sonrası hiperglisemideki düzelme ve bunun sonucu VEGF'deki azalma, idrar albümin/kreatinin oranındaki düşüşle endokan düzeylerindeki azalma arasındaki paralelliği izah edebilir. Karşıt olarak Çıkrıkçıŏglu ve ark. diyabetik hastalarda albüminüri düzeyleri ile endokan düzeyleri arasında ters bir ilişki olduğunu bildirmişlerdir (31). Bizim çalışmamızda makroalbüminürik hastalarda mikroalbüminürik olanlara göre plazma endokan düzeyleri anlamlı derecede yüksek idi. Ancak kontrol grubuna göre anlamlı bir fark bulunamadı. Plazma endokan düzeylerinin çevresel faktörlerle, tedaviyle değişiklik göstermesi bu sonuçlarda etkili olmuş olabilir.

Çalışmamız diyabetik olguların dahil edildiği bir vaka kontrol çalışmasıdır. Olgu sayısının az olması, tek merkezli bir çalışma olması çalışmamızın kısıtlılıkları arasında sayılabilir. Bu kısıtllıklara rağmen diyabetik komplikasyonların oluşumunda vasküler disfonksiyon gelişiminin yer tutması nedeni ile vasküler endotel, mediyatörler arası etkileşim ve inflamasyon örgüsü için belirteç olarak kabul edilen serum ADMA ve endokan düzeylerinin irdelenmesi açısından $1 s ̧ 1 \mathrm{k}$ tutucu nitelikte olduğunu düşünmekteyiz. Bu çalışmanın sonuçlarına göre diyabetik komplikasyonların öngörülmesinde tek başına plazma ADMA düzeyi ölçümüne ilaveten endokan düzeylerinin tespiti ek bir katkı sağlamamaktadır.

Çalışmamız kronik düşük düzey inflamasyonun eşlik ettiği DM hastalarında vasküler disfonksiyon belirteci olarak serum ADMA düzeylerinin kullanılabileceği hipotezini desteklemektedir. Ancak hastalık patofizyolojisinde yer alan inflamasyon göstergesi olarak plazma endokan düzeyleri arasında ilişki bulunamakla birlikte serum ADMA ile endokan düzeylerinin birlikte ölçümünün hastalık progresyonu öngörüsünde ek katkısının kısıtlı olduğu şeklinde yorumlanabilir. Diyabet hastalarında özellikle mikrovasküler komplikasyonların gelişmesinde serum ADMA düzeyleri önem arz etmektedir. Nefropati gelişmiş olan diyabetik hastalarda serum ADMA ve endokan düzeylerinin endotelyal disfonksiyonu göstermekte anlamlı olduğu saptanmıştır.

\section{KAYNAKLAR}

1. Satman İ, İmamoğlu Ş, Yılmaz C, Akalın S, Salman S, Dinççă̆ N. Diabetes Mellitus ve komplikasyonlarının tanı, tedavi ve izlem kılavuzu. Türkiye Endokrinoloji ve Metabolizma Derneği Ankara Erişim: http://temd.org.tr/admin/uploads/ tbl_kilavuz/20180516162547-2018-05-16tbl_kilavuz162544. pdf Erişim tarihi: 16-05-2018

2. Bilici M, Arpaci DK, Ilikhan SU, Corakci BD, Bayraktaroglu T, Arasli M, et al. Type 2 Diabetes Mellitus Associated with Premature Aging. Iranian Red Crescent Medical Journal. 2017;19(6).

3. Herder C, Bongaerts BW, Rathmann W, Heier M, Kowall B, Koenig W, et al. Association of subclinical inflammation with polyneuropathy in the older population: KORA F4 study. Diabetes Care. 2013;36(11):3663-70.

4. Hu H, Jiang H, Ren H, Hu X, Wang X, Han C. AGEs and chronic subclinical inflammation in diabetes: disorders of immune system. Diabetes/metabolism research and reviews. 2015;31(2):127-37.

5. Erbil MK, Kurt YG, Yaman H, Çakır E, Akgül EÖ, Çaycı T. Asimetrik dimetilarjininin metabolizması ve klinik önemi. Turkish Journal of Biochemistry/Turk Biyokimya Dergisi. 2012;37(1).

6. Sarrazin S, Adam E, Lyon M, Depontieu F, Motte V, Landolfi C, et al. Endocan or endothelial cell specific molecule-1 (ESM1): a potential novel endothelial cell marker and a new target for cancer therapy. Biochimica et Biophysica Acta (BBA)Reviews on Cancer. 2006;1765(1):25-37.

7. Balta S, Mikhailidis DP, Demirkol S, Ozturk C, Celik T, Iyisoy A. Endocan: a novel inflammatory indicator in cardiovascular disease? Atherosclerosis. 2015;243(1):339-43.

8. Olokoba AB, Obateru OA, Olokoba LB. Type 2 diabetes mellitus: a review of current trends. Oman medical journal. 2012;27(4):269.

9. Rodríguez AJ, dos Santos Nunes V, Mastronardi CA, Neeman T, Paz-Filho GJ. Association between circulating adipocytokine concentrations and microvascular complications in patients with type 2 diabetes mellitus: A systematic review and metaanalysis of controlled cross-sectional studies. Journal of diabetes and its complications. 2016;30(2):357-67.

10. Hwang M-H, Kim S. Type 2 diabetes: endothelial dysfunction and exercise. Journal of exercise nutrition \& biochemistry. 2014;18(3):239.

11. Temelkova-Kurktschiev T, Siegert G, Bergmann S, Henkel E, Koehler C, Jaro W, et al. Subclinical inflammation is strongly related to insulin resistance but not to impaired insulin secretion in a high risk population for diabetes. MetabolismClinical and Experimental. 2002;51(6):743-9.

12. Dhananjayan R, Koundinya KS, Malati T, Kutala VK. Endothelial dysfunction in type 2 diabetes mellitus. Indian Journal of Clinical Biochemistry. 2016;31(4):372-9.

13. Özdoğu H. İnflamasyonda Bir Baş Aktör: Endotel.http://www. thd.org.tr/thdData/userfiles/file/6_IBK_03.pdf 
14. Sena CM, Pereira AM, Seiça R. Endothelial dysfunction A major mediator of diabetic vascular disease. Biochimica et Biophysica Acta (BBA) - Molecular Basis of Disease. 2013;1832(12):2216-31.

15. Aburawi EH, AlKaabi J, Zoubeidi T, Shehab A, Lessan N, Al Essa A, et al. Subclinical Inflammation and Endothelial Dysfunction in Young Patients with Diabetes: A Study from United Arab Emirates. PLOS ONE. 2016;11(7):e0159808.

16. Buğdaycı G, Serin E. Asimetrik Dimetilarginin (ADMA). Düzce Tıp Fakültesi Dergisi 2005; 2: 36-41

17. Yılmaz M, Eyileten T, Yenicesu M. Kronik böbrek hastalığında yeni bir oyuncu: Asimetrik dimetilarginin (ADMA). Türk Nefroloji Diyaliz ve Transplantasyon Dergisi. 2007;16(3):93101.

18. Işıklar ÖÖ, Mutaf I. Asimetrik dimetilarginin ve klinik önemi. Türk Klinik Biyokimya Derg. 2010;8(2):75-89.

19. Krzyzanowska K, Mittermayer F, Wolzt M, Schernthaner G. ADMA, cardiovascular disease and diabetes. diabetes research and clinical practice. 2008;82:S122-S6.

20. Taşkıran B, Altun BU, Vardar SA, Demir AM, Karadağ ÇH, Altun A. Effect of Exercise on ADMA Level in Type 2 Diabetes Mellitus. Balkan Medical Journal. 2014;2012(1):62-7.

21. Abbasi F, Asagmi T, Cooke JP, Lamendola C, McLaughlin $\mathrm{T}$, Reaven GM, et al. Plasma concentrations of asymmetric dimethylarginine are increased in patients with type 2 diabetes mellitus. The American journal of cardiology. 2001;88(10):1201-3.

22. Konya H, Miuchi M, Satani K, Matsutani S, Yano Y, Tsunoda $\mathrm{T}$, et al. Asymmetric dimethylarginine, a biomarker of cardiovascular complications in diabetes mellitus. World journal of experimental medicine. 2015;5(2):110.

23. Altınova AE, Arslan M. Endokrin hastalıklarda asimetrik dimetilarjinin (ADMA). Marmara Medical Journal. 2009;22(1):80-4.
24. Lin KY, Ito A, Asagami T, Tsao PS, Adimoolam S, Kimoto M, et al. Impaired nitric oxide synthase pathway in diabetes mellitus: role of asymmetric dimethylarginine and dimethylarginine dimethylaminohydrolase. Circulation. 2002;106(8):987-92.

25. Assal HS, Younes K, Alsayed A, Hasan N, Ali AR. Asymmetric dimethylarginine (ADMA) and progression of nephropathy in patients with type 2 diabetes. Kidney. 2009;18(5):247.

26. Malecki MT, Undas A, Cyganek K, Mirkiewicz-Sieradzka B, Wolkow P, Osmenda G, et al. Plasma asymmetric dimethylarginine (ADMA) is associated with retinopathy in type 2 diabetes. Diabetes Care. 2007;30(11):2899-901.

27. Pitsavos C, Tampourlou M, Panagiotakos DB, Skoumas Y, Chrysohoou C, Nomikos T, et al. Association between lowgrade systemic inflammation and type 2 diabetes mellitus among men and women from the ATTICA study. The review of diabetic studies: RDS. 2007;4(2):98.

28. Kose M, Emet S, Akpinar TS, Kocaaga M, Cakmak R, Akarsu $\mathrm{M}$, et al. Serum endocan level and the severity of coronary artery disease: a pilot study. Angiology. 2015;66(8):727-31.

29. Abu El-Asrar AM, Nawaz MI, De Hertogh G, Al-Kharashi AS, Van den Eynde K, Mohammad G, et al. The angiogenic biomarker endocan is upregulated in proliferative diabetic retinopathy and correlates with vascular endothelial growth factor. Current eye research. 2015;40(3):321-31.

30. Arman Y, Akpinar TS, Kose M, Emet S, Yuruyen G, Akarsu M, et al. Effect of glycemic regulation on endocan levels in patients with diabetes: a preliminary study. Angiology. 2016;67(3):23944.

31. Cikrikcioglu MA, Erturk Z, Kilic E, Celik K, Ekinci I, Yasin Cetin AI, et al. Endocan and albuminuria in type 2 diabetes mellitus. Renal failure. 2016;38(10):1647-53. 